\title{
Factors Influencing the Students' Acceptance of E-Learning at Teacher Education Institute: An Exploratory Study in Malaysia
}

\author{
Muhamad Suhaimi Taat ${ }^{1} \&$ Agatha Francis $^{2}$ \\ ${ }^{1}$ Faculty of Psychology and Education, Universiti Malaysia Sabah, Malaysia \\ 2 Teacher Education Institute Batu Lintang, Kuching Sarawak, Malaysia \\ Correspondence: Muhamad Suhaimi Taat, Faculty of Psychology and Education, Universiti Malaysia Sabah, \\ Malaysia. E-mail: suhaimi@ums.edu.my
}

Received: October 13, 2019

Accepted: December 3, $2019 \quad$ Online Published: December 4, 2019

doi:10.5430/ijhe.v9n1p133

URL: https://doi.org/10.5430/ijhe.v9n1p133

\begin{abstract}
This study aimed to identify the level of e-learning acceptance, and factors that influence it, among students at a teacher education institute in Malaysia. Factors involved in the study were usability perceptions, ease of use, lecturer characteristics, information quality, system quality, and technical support. A total number of 230 students were selected as respondents from the third- and final-year students from various undergraduate programmes that employed e-learning. The instrument used in this study consisted of a set of questionnaires containing 49 question items and using five-point Likert scales. The results of the study were analysed using descriptive statistics that derived means and standard deviations. The results show that the key factors influencing the acceptance of e-learning among the students are usability, lecturer characteristics, system quality, the information provided, and available technical support. The findings also show that students' acceptance of e-learning is influenced by the benefits and usefulness of the programme and, as well, saving time and receiving course content that is simple and appropriate to the task.
\end{abstract}

Keywords: e-learning, technology, acceptance, model, usability

\section{Introduction}

In the wake of recent technological breakthroughs, the use of e-learning for pedagogical applications has become very important. Teacher-training institutes are not left behind in the use of e-learning for communicating, delivering, and facilitating information-sharing more effectively. Students can connect via the Internet via such media as 'chat', 'instant messaging', online discussions, e-mail, SMS, MMS, and more. The e-learning provided and developed by the institute is based on Moodle software called Online Learning (OLL). Online learning is an approach widely used as an information-delivery and database system for managing, communicating content, interacting, or facilitating teaching and learning activities. However, the emergence of web 2.0 applications such as Facebook, Twitter, blog, Instagram, WhatsApp, and WeChat have become rivals to the Learning Management System (LMS) provided by the institute. The features and functionality provided by web 2.0 have captivated students and provided a new opportunity for them to actively use the applications.

Usually, e-learning is more popular in universities or colleges that offer in online and distance learning courses. Today, teacher education institutes are also not left behind in introducing online learning to students (either full-time or part-time). E-learning at the Institute was introduced in 2003. The purpose of integrating the e-learning approach with more traditional methods is to enable students to interact with their lecturers and peers at their own pace. Additionally, students can access materials or resources anywhere and at any time. Thus, e-learning promotes the process of self-learning among students (i.e. eliminating reliance on lecturers and, as well, building bilateral communication between students and lecturers and students with friends.

However, students cannot avoid facing problems and obstacles when using e-learning. A study conducted by Mohd Sukri et al. (2007) found that e-learning acceptance is constrained, in part, by its own characteristics (i.e. less interesting than other forms of learning, not friendly, and not sufficiently interactive to make students feel more connected to the faculty and friends through such platforms as Facebook, Whatsapps, Wechat, and email). The study by Ab Hamid et al. (2014) showed that the perceived usefulness of a blog did not influence students' acceptance of it and was only at moderate level. This study was similar to that conducted by Kusuma (2008), who found that 
usability and ease of use did not influence e-learning acceptance. Therefore, the findings of these researchers are inconsistent. In this regard, the current study aims to fill in the gaps of past research in the context of Sarawak, Malaysia.

As the e-learning system has become widely used at the teacher's education institute, it is very important to explore students' acceptance of this programme, as provided by the institute. Although there might be problems or obstacles that can negatively impact students' use of e-learning, such features can be improved and overcome with the cooperation of various parties. Therefore, this study was conducted to identify factors that influence the acceptance of students using e-learning at the institute. This study also aimed to examine the level of student acceptance of e-learning at the level of teacher education.

\section{Research Question}

The research questions of this study are:

1. What is the level of student acceptance of e-learning.

2. What are the factors that influence the acceptance of students using e-learning at the Institute.

\section{Literature Review}

The adoption of technology for education has been widely discussed by researchers by incorporating various theories and models (Sharma \& Chandel, 2013) but in different contexts, cultures, and environments. The most commonly used theories and models are: Technology Acceptance Model (TAM), Unified Theory of Acceptance and Use of Technology (UTAUT), Extension of TAM, Innovation Diffusion Theory (IDT), Reasoned Action Theory (RAT) and Theory of Planned Behaviour (TPB). These theories and models have various meanings, belief systems supporting them, and benefits they provide for researchers. Nonetheless, those theories and models are still popular and relevant in research.

In this study, six factors were adapted from existing theories, models, and previous studies related to e-learning acceptance by students. Two factors, namely usability perceptions and ease of use, were adapted from TAM (Davis, 1989), while system quality and information quality were adapted from the Information Systems Success Model (DeLone \& McLean, 2003); lecturer characteristics and technical support were adapted from previous studies. such as Waheed and Hussain (2010), Malik (2009), Sun et al. (2008), and Selim (2007). According to Davis (1989), usability and ease of use can influence consumers' desire to use e-learning technology and subsequently influence their use of the system. 'Usefulness' refers to how well a person believes that using a particular system will improve their performance; it also refers to how much one believes that the system can be used easily and independently or otherwise (Davis, 1989). Conceptual perceptions also influence the notion of usefulness (i.e. if one thinks the system is easy to use then the system is useful to him/her). To ensure the usability and ease of use of our users, the quality of the system and the quality of information must be taken into account.

According to the IS Success Model, system quality refers to the measurement of technical success, while information quality measures semantic success (DeLone \& McLean, 2003). Both these factors are expected to promote the use of the system as well as influence its acceptance by the user - and, ultimately, the organisation as a whole. For the system to succeed, technical support from the administration is crucial. Failure to provide support will frustrate consumers and, as a result, put the technology in a negative light. Besides, lecturers play an important role in encouraging students to use the e-learning system. Waheed and Hussain (2010) and Sun et al. (2008) agreed that lecturers' characteristics can contribute to e-learning acceptance and student satisfaction. In addition, the success of the e-learnitng system depends on the lecturer's attitude towards such a programme. Not only the attitude towards the system, but the role of lecturers in the management of e-learning, dissemination of information, teaching style, and provision of relevant and quality information and content can provide satisfaction and thereby promote acceptance of e-learning among the students.

\section{Method}

The method used in this study was the descriptive survey method (e.g. using a questionnaire as the research instrument to provide an overview of e-learning acceptance among students). According to Yahya Don (2006), descriptive surveys enable researchers to collect a variety of information and measure the variables associated with a phenomenon. The questionnaire instrument makes it easy to obtain the exact information needed based on the research question. In fact, use of a questionnaire is simple, inexpensive, fast, and time-saving (Jas Laile, 2008). 


\subsection{Sampling Procedure}

The current sample consisted of 230 students of third- and fourth-year students from various programmes who used e-learning at the teacher education institute in Sarawak, Malaysia. They were chosen by using stratified and simple random sampling. According to Krejcie and Morgan's (1970), the minimum number for a population of 380 is 191. This figure is considered sufficient in this study based on Chua (2006), which states that the minimum percentage of the sample for a study is only $30 \%$ of the study population.

\subsection{Instrument}

In this study, a set of questionnaires containing seven sections was prepared and administered. Part A: Student Background; Part B: Perceptions of Usability; Part C: Constructive Impressions; Part D: Lecturer Features; Part E: System Quality; Part F: Technical Support and Part G: Quality of Information. These questionnaire were adapted and modified from previous studies such as Waheed and Hussain (2010), Ab Hamid et al. (2014), Song (2010), Sun et al. (2008), Selim (2007), DeLone and McLean (1992, 2003), Davis, Bagozzi, and Warshaw (1993) and Davis (1989). The questionnaire used a Likert scale consisting of 5 possible responses (Strongly Disagree, Disagree, Strongly Agree, Agree and Strongly Agree); it examined factors that influence e-learning acceptance among students.

\subsection{Pilot Study}

A pilot study was conducted to check the reliability of the instruments. The Cronbach alpha obtained was 0.90, which indicated that the questionnaire could be used for this study. This is because instruments with coefficients greater than 0.80 are considered to have high reliability (Cohen et al., 2007).

\subsection{Data Analysis}

The data obtained from the questionnaire were analysed using SPSS software, version 20.0 Items in Section A were analysed in terms of frequency and percentage. Items in Parts B through G were analysed based on descriptive statistics using percentage, mean, and standard deviation.

\section{Findings}

\subsection{Level of Student Acceptance of E-learning}

The findings of the study, as presented in Table 1, show that the respondents overall showed a high level of acceptance of e-learning. Usability and ease-of-use factors recorded a mean score of 4.00 and the mean score of lecturers was 3.98, while the mean score of the system quality factor was 3.97 and the information quality factor mean score was 3.87. In addition, the technical support factor recorded the lowest mean score (3.64). Thus, this finding shows that the level of e-learning acceptance among students is influenced by usability, convenience, lecturer characteristics, system quality, information quality, and technical support.

Table 1. Student Acceptance Statistics ( $=230)$

\begin{tabular}{ccc}
\hline Factors & Mean & Std. Deviation \\
\hline Usability & 4.00 & 0.70 \\
Easy-to-use & 4.00 & 0.54 \\
Lecturer & 3.97 & 0.58 \\
System Quality & 3.98 & 0.60 \\
Technical Support & 3.64 & 0.84 \\
Information Quality & 3.87 & 0.60 \\
\hline
\end{tabular}

\subsection{Factors Influencing E-Learning Acceptance}

There are six e-learning acceptance factors studied in this study. These are usability factors, usability factors, lecturer features, system quality factors, information quality factors, and technical support factors.

\subsubsection{Usability Factor}

In terms of the usability factors influencing respondents' acceptance, the study achieved a mean score of $4.00(\mathrm{SD}=$ 0.70). According to Table 2, all items had a mean score at the high level (except for three items with mean values at the medium level: Item 1, E-learning improves learning performance $(M=3.98)$, Items 8 and 10 , which both had a mean score of 3.92. This means that e-learning respondents only supported critical aspects of learning. In addition, respondents agreed that taking an online course increased their productivity. Seven items (Items 2, 3, 4, 5, 6, 7, and 9) 
showed a mean value above 4.0. This indicates that the usability factor had a positive impact on the acceptance and use of e-learning among respondents. Respondents believed that e-learning could enhance understanding and effectiveness of learning; it also was thought to be very useful and easy to use.

Table 2. Mean and Standard Deviation of the Usefulness Factor $(\mathrm{N}=230)$

\begin{tabular}{cccc}
\hline No. & Item & Mean & Std. Deviation \\
\hline 1 & E-learning improves my learning performance & 3.98 & 0.69 \\
2 & E-learning increases my level of understanding & 4.03 & 0.65 \\
3 & E-learning enhances my learning effectiveness & 4.00 & 0.68 \\
4 & I find the e-learning system very useful for me & 4.01 & 0.70 \\
5 & Through e-learning, the content of the course is easier to & 4.03 & 0.70 \\
6 & learn & 4.08 & 0.68 \\
7 & E-learning improves the quality of my assignments & 0.74 \\
8 & E-learning supports any aspect that is considered critical to & 3.92 & 0.72 \\
9 & learning & 4.02 & 0.72 \\
10 & E-learning enables work to be completed faster & 3.92 & 0.74 \\
& Taking online courses increased my productivity & 4.00 & 0.70 \\
\hline
\end{tabular}

\subsubsection{Useful Factor}

The second factor studied in influencing e-learning is the useful (convenience) factor. Table 3 shows the data analysis of usability factors in e-learning acceptance. There are ten items designed to test the usability of e-learning on student acceptance. The findings show that the factor of ease of use in influencing e-learning recorded a mean of 4.00 ( $\mathrm{SD}=0.68$ ). Four items (Item 15, E-learning provides accurate information $[\mathrm{M}=3.88]$; Item 16, E-learning provides good information [M $=3.97]$, Item 17, E-learning provides accurate information on time [M $=3.90]$ and Item 20, E-learning provided detailed information $[\mathrm{M}=3.95]$. This means that respondents agree that e-learning can provide accurate, good, detail, timely, and accurate information.

Table 3. Mean and Standard Deviation of the Usable Factor $(\mathrm{N}=230)$

\begin{tabular}{cccc}
\hline No. & Item & Mean & Std. Deviation \\
\hline 11 & E-learning will save your time to get reference material & 4.13 & 0.69 \\
12 & I feel comfortable using e-learning & 4.03 & 0.70 \\
13 & I found the e-learning system easy to use & 4.00 & 0.72 \\
14 & E-learning is very useful to me & 4.06 & 0.69 \\
15 & E-learning provides accurate information & 3.88 & 0.72 \\
16 & E-learning provides good information & 3.97 & 0.70 \\
17 & E-learning provides timely information & 3.90 & 0.69 \\
18 & E-learning provides relevant information & 4.05 & 0.64 \\
19 & E-learning provides easy-to-understand information & 4.06 & 0.63 \\
20 & E-learning provides detailed information & 3.95 & 0.66 \\
& Mean & 4.00 & 0.68 \\
\hline
\end{tabular}

\subsubsection{Lecturer's Factor}

The third factor is lecturer characteristics in influencing e-learning. The findings show that lecturer characteristics influence respondents' acceptance of e-learning with a mean score of 3.98 ( $\mathrm{SD}=0.77)$, as shown in Table 4. There were two items with the highest mean scores (Item 27, lecturers encourage students to participate in classes and Item 23, tutors are friendly to each student). These items recorded mean scores of 4.13 and 4.08, respectively. Item 29, 
tutor actively taught the subject through e-learning, received the lowest mean score $(\mathrm{M}=3.89)$, followed by Item 25 , tutor explained how to use the e-learning system. Table 4 also shows three items with mean scores above 4.00 and six items averaging over 3.00. This indicates the factors influencing lecturers' influence on e-learning among respondents.

Table 4. Mean and Standard Deviation of Lecturer Characteristics Factor $(\mathrm{N}=230)$

\begin{tabular}{cccc}
\hline No. & Item & Mean & Std. Deviation \\
\hline 21 & Lecturer are excited to teach the class & 3.96 & 0.78 \\
22 & The style of lecturer's delivery caught my attention & 3.92 & 0.80 \\
23 & Student-friendly lecturer & 4.08 & 0.73 \\
24 & Lecturer handle e-learning effectively & 3.97 & 0.77 \\
25 & Lecturer explain how to use the e-learning system & 3.91 & 0.80 \\
26 & Lecturer are happy when we use e-learning to interact & 3.95 & 0.79 \\
27 & with & 4.13 & 0.70 \\
28 & Lecturer encourage students to participate in the class & 4.03 & 0.75 \\
29 & Lecturer encouraged me to use e-learning & 3.89 & 0.79 \\
& Mean & 3.98 & 0.77
\end{tabular}

\subsubsection{System Quality Factors}

The fourth factor studied is the system quality factor in e-learning acceptance. Table 5 shows the data analysis of system quality factors in e-learning acceptance. There are eight items to measure system quality factors in e-learning acceptance among students. The system quality factor in e-learning acceptance recorded a mean score of $3.97(\mathrm{SD}=$ 0.76). This shows that system quality factors affect e-learning acceptance at a moderate level. The study found five items (Items 30, 31, 33, 36, and 37) at the moderate level, with mean scores above 3.00. Apart from that, three items (Items 32, 34, and 35 were at the high level with mean scores above 4.00 (see Table 5). In addition, Item 37, which is more to learn in online courses than face-to-face courses, had the lowest mean score of 3.60. This indicates that respondents still prefer a face-to-face approach to assist with their learning process.

Table 5. Mean and Standard Deviation for System Quality Factors $(\mathrm{N}=230)$

\begin{tabular}{|c|c|c|c|}
\hline No. & Item & Mean & Std. Deviation \\
\hline 30 & $\begin{array}{l}\text { Using e-learning allows me to select topics to learn according to } \\
\text { my priority }\end{array}$ & 3.99 & 0.76 \\
\hline 31 & E-learning allows me to learn at my pace & 3.93 & 0.72 \\
\hline 32 & $\begin{array}{l}\text { E-learning gives me the flexibility to study topics anytime and } \\
\text { anywhere }\end{array}$ & 4.02 & 0.72 \\
\hline 33 & $\begin{array}{l}\text { E-learning allows me to learn lessons in a customised form of } \\
\text { my learning style }\end{array}$ & 3.96 & 0.74 \\
\hline 34 & $\begin{array}{l}\text { E-learning allows me to get information through online sources } \\
\text { (e.g. Wikipedia, Internet, search engine) }\end{array}$ & 4.22 & 0.66 \\
\hline 35 & $\begin{array}{l}\text { Using e-learning allows me to interact with friends and work } \\
\text { together on assignments }\end{array}$ & 4.05 & 0.73 \\
\hline 36 & Using online courses according to my lifestyle & 3.96 & 0.74 \\
\hline \multirow[t]{2}{*}{37} & Learn more in online courses than face-to-face courses & 3.60 & 1.00 \\
\hline & Mean & 3.97 & 0.76 \\
\hline
\end{tabular}




\subsubsection{Technical Support Factor}

The fifth factor studied is technical support. The findings showed that technical support factors strongly influence respondents' acceptance of e-learning (with a mean value of 3.64; see Table 6. All items recorded mean scores above 3. Items accessing the institute's e-learning site using the internet are provided and the institute provides all the necessary facilities for e-learning with the lowest mean of 3.47 and 3.56, respectively. Respondents agreed that the provision of e-learning tools and the opportunity to use e-learning could influence respondents' acceptance of e-learning by recording mean scores of 3.77 and 3.76 respectively.

Table 6. The Mean and Standard Deviation of the Technical Support Factor $(\mathrm{N}=230)$

\begin{tabular}{|c|c|c|c|}
\hline No. & Item & Mean & Std. Deviation \\
\hline 38 & $\begin{array}{l}\text { The Institute provides all the facilities I need for } \\
\text { e-learning }\end{array}$ & 3.56 & 1.03 \\
\hline 39 & $\begin{array}{l}\text { I can access the Institute's e-learning site using the } \\
\text { internet provided }\end{array}$ & 3.47 & 1.12 \\
\hline 40 & Institutes allowed to use e-learning & 3.76 & 0.91 \\
\hline 41 & $\begin{array}{l}\text { The Institute provided training for me to use } \\
\text { e-learning tools }\end{array}$ & 3.77 & 0.90 \\
\hline \multirow[t]{2}{*}{42} & $\begin{array}{c}\text { Technical assistance is required when using } \\
\text { e-learning }\end{array}$ & 3.64 & 0.95 \\
\hline & Mean & 3.64 & 0.98 \\
\hline
\end{tabular}

\subsubsection{Information Quality Factors}

The last factor studied is the information quality factor in e-learning acceptance. Table 7 shows the data analysis of information quality factors in this area. There are seven items devoted to testing information quality factors in e-learning acceptance among students. The information quality factor in overall e-learning acceptance recorded a mean of 3.87 and a deviation of 0.77 . This shows that the information quality factor in e-learning acceptance is at a moderate level. All items had an average mean score except for one item with a high mean score (Item 46, Finding information through the course website was easy; $M=4.00$ ). This shows that respondents agreed that finding information through the website is easy. Item 49, Likes online courses from face-to-face courses had the lowest mean of 3.65 , followed by Item 48, Course materials loaded online at the time specified and Item 43, The course content provided was sufficient obtained 3.82 and 3.83 , respectively.

Table 7. Mean and Standard Deviation for Information Quality Factor $(\mathrm{N}=230)$

\begin{tabular}{cccc}
\hline No. & Item & Mean & Std. Deviation \\
\hline 43 & The content the course provided was sufficient & 3.83 & 0.78 \\
44 & $\quad$ Course content related to subject & 3.89 & 0.74 \\
45 & The structure of e-learning components is easy to & 3.91 & 0.75 \\
$\quad$ understand & & 0.69 \\
46 & Finding information through the course website is & 4.00 & 0.72 \\
47 & $\quad$ The e-learning component has always existed & 3.96 & 0.77 \\
48 & Course materials loaded online at the specified time & 3.82 & 0.92 \\
49 & Likes online courses from face-to-face courses & 3.65 & 0.77 \\
\hline
\end{tabular}




\section{Discussion}

From the results of the analysis, it was found that the mean score of the usability and ease of use factors influencing e-learning acceptance was 4.00. This shows that students reported a positive attitude toward e-learning and believe that it benefits them. The findings of this study are in line with that of Davis et al. (1989) and Davis (1989), who explained that the usability and ease-of-use factors in TAM theory had a positive impact on the use of e-learning technology. This statement was supported by Ahmad Althumibat et al. (2012), who found that usability and convenience perceptions influenced consumer acceptance of technology-assisted products and services. According to them, products and services that are cost-effective and easy to use will affect consumer acceptance of services provided. In contrast to a study conducted by Ab Hamid et al. (2014) and Kusuma (2008), who explained that the usefulness factor did not affect the acceptance of e-learning among users. Therefore, the findings of this study are different and inconsistent with previous studies. The differences in the findings can be influenced by other factors. The lecturer's factor recorded a mean score of 3.98. This indicates that the role of the lecturer in influencing the reception is positive. The findings of this study are in line with those of Waheed and Hussain (2010) and Malik (2009), who found that users felt the need to interact with the instructor or lecturer to solve problems. Interactions between the student and lecturer enable learners to interact with lecturers when encountering problems in doing assignments. The guidance and encouragement of the lecturers can motivate students to use e-learning, by these means, they will indirectly embrace the system. Besides, engaging presentation, systematic teaching style, and friendly interaction are among the factors that encourage students to accept and encourage them to continue to use the e-learning system. This is supported by Sun et al. (2008), who suggested that teachers' attitudes toward e-learning are important as they can positively impact students' acceptance of the modality.

Next, the system quality factor recorded a mean score of 3.97 and the information quality factor recorded a mean score of 3.87. Both of these factors are important and will also influence e-learning. The findings of this study are supported by Song (2010) and Sun et al. (2008), who found that students who use e-learning have the opportunity to practice self-directed learning. According to Sun et al. (2008), students can use e-learning anywhere and anytime. Most students agreed that the flexibility of e-learning systems and online resources can facilitate and assist them in their assignments. Flexible systems with sufficient content and high-quality information will meet the needs and satisfaction of students. However, it should be noted that the learning institutions should have excellent internet coverage to enable students to access materials and resources that are fast and easy.

Therefore, technical support plays an important role in e-learning adoption and implementation. The results on this factor obtained a mean score of 3.64 (the lowest among other factors). This finding is in line with those of Waheed and Hussain (2010) and Malik (2009), who obtained similar results. This means that the technical support provided by institution's management is still not satisfactory in the use of e-learning. As such, the Teacher Education Institute needs to improve the existing e-learning system to encourage students to continue using it. Technical support can reduce the external problems students often face such as slow internet access, low signal, sign-in problems, and so on.

\section{Conclusion}

The e-learning approach is very important as a means of diversifying teaching and learning methods among lecturers and students. This study found that the level of e-learning acceptance among students was modest and influenced by factors such as usability and ease of use. The usefulness and convenience of students are influenced by the quality of the system provided by the Institute and the information provided by the lecturers. However, technical support should be taken into consideration by the Institute because of external issues such as slow internet access, low signal, sign-in problems, less user-friendly interface, and less attractive e-learning websites that can cause students not to use the modality. Other services such as internet and broadband should be improved, as the internet is at the heart of e-learning use and acceptance.

The findings of this study have implications for management, lecturers, researchers, and students. The study could increase the knowledge of e-learning as relates to its usage and acceptance. For students and lecturers, e-learning systems can facilitate learning and teaching, as the modality can be implemented anywhere and at any time, as long as the place or location has internet access. This study also provides a clear picture of the administration and management as well as the lecturers on e-learning-related issues so that steps can be taken accordingly. Furthermore, this study encourages lecturers to use e-learning in helping to enhance their teaching process. Apart from that, this study also increased the amount of research in the field of e-learning and provided a source of reference for other researchers to conduct further studies.

Recommendations for future studies should focus on improving research methods, additional variables and 
respondents in a broader context to reach a better conclusion. This study used only students as respondents. A recommendation for future studies is to involve the lecturers for more comprehensive and robust information and views. In terms of research methods, it is suggested that, in the future, studies be conducted through two approaches, namely, quantitative and qualitative (mixed-methods), in order to be more robust (Aini Hassan, 2007). Based on quantitative studies, respondents were not able to provide such subjective information, as respondents were controlled by a structured questionnaire (Aini Hassan, 2007). For the future, in addition to the printed questionnaire, respondents can provide information or answer the questionnaire through online methods, as it is easier to analyse in that format (Wright, 2005).

On behalf of management, the Institute should take appropriate steps to implement the e-learning system carefully and efficiently. Assessment and monitoring of usage should be carried out so that all students and faculty use the existing e-learning system more effectively and effectively. Improving the quality of internet or broadband access should be addressed appropriately, to ensure that students have good access and to promote the use of the system.

\section{Acknowledgements}

Proof reading done by Proof-Reading-Service.com

\section{References}

Ab. Hamid Ali, Fadzli Adam, \& Wong, Wan Solihin Abdullah. (2014). Acceptance of the blog as a religious medium among Malaysian high school students. Proceeding of the International Conference on Arabic Studies and Islamic Civilization iCasic 2014, 4-5 March 2014, Kuala Lumpur, MALAYSIA.

Ahmad Althunibat, Nor Azan Mat Zin, \& Noraidah Sahari. (2012). Modeling factor of acceptance of mobile government services (M-Government). Asia-Pacific Journal of Information Technology and Multimedia, 1(1). 21-37. https://doi.org/10.5171/2011.141651

Aini Hassan. (2007). Qualitative or quantitative?: Understand the underlying assumptions underlying educational research. Educational Issues, 30 (1), 7-16.

Al-Adwan, A., Al-Adwan, A., \& Smedley, J. (2013). Exploring students acceptance of e-learning using Technology Acceptance Models in Jordanian universities. International Journal of Education and Development using Information and Communication technology (IJEDICT), 9 (2), 4-18.

Ali, A., Muhammad I. Ramay \& Mudasar Shahzad. (2010). Key factors for determining student satisfaction in distance learning courses: A study of Allama Iqbal Open University (AIOU) Islamabad, Pakistan. Malaysian Journal of Distance Education, 12 (2), 33-51.

Aypay, A., Celik, H. C., Aypay, A., \& Sever, M. (2012). Technology acceptance in education: a study of pre-service teachers in Turkey. TOJET: The Turkish Online Journal of Educational Technology, 11 (4), 264-272.

Ball, D., \& Levy, Y. (2009). Emerging educational technology: Assessing the factors that influence instructors' acceptance in information systems and other classrooms. Journal of Information Systems Education, 19 (4), 431-443.

Chua, Y. P. (2006). Methods of research: Book 1. Kuala Lumpur: McGraw-Hill.

Cohen, L., Manion, L. \& Morrison, K. (2007). Research methods in education. 6th ed. New York: Routledge. https://doi.org/10.4324/9780203029053

Davis, F. D. (1989). Perceived usefulness, perceived ease of use, and user acceptance of information technology. MIS Quarterly, 13 (3), 318-339. https://doi.org/10.2307/249008

Davis, F. D., Bagozzi, R. P., \& Warshaw, P. R. (1989). User acceptance of computer technology: A comparison of two theoretical models. Management Science, 35 (8), 982-1003. https://doi.org/10.1287/mnsc.35.8.982

Delone, W. H., \& McLean. E. R. (2003). The Delone and McLean Model of information systems success: A Ten-Year update. Journal of Management Information System, 19, 9-30. https://doi.org/10.1080/07421222.2003.11045748

Jas Laile Suzana Jaafar. (2008). Introduction to the psychology of children and adolescents. Shah Alam: Education Directions.

John Don. (2006). Social psychology in education. Kuala Lumpur: PTS Professional Publishing

Krejcie, R. V., \& Morgan, D. W. (1970). Determining sample size for research activities. Educational and Psychological Measurement, 30, 607-610. https://doi.org/10.1177/001316447003000308 
Kusuma, Hadri. (2008). Modeling of Information Technology Acceptance: The role of personal values, speech. Human - Computer Studies, 64, 683-696.

Lee, B. C., Yoon, J. O., \& Lee, I. (2009). Learners' acceptance of e-learning in South Korea: Theories and results. Computers and Education, 53, 1320-1329. https://doi.org/10.1016/j.compedu.2009.06.014

Malik, M. W. (2009). Student satisfaction towards e-learning: Influential role of key factors. 2nd CBRC Proceedings, Lahore, Pakistan.

Mohamad Najib Abdul Ghafar. (2003). Educational Research. Skudai: University of Technology Publishing Malaysia.

Muhammad Sukri Saud, Mohd Anuar Abdul Rahman, \& Ting, K. S. (2007). Studies on the use of e-learning among technical and vocational education students in higher education institutions of Johor. 1st International Malaysian Educational Technology Convention, UTM Skudai, Johor.

Selim, H. M. (2007). Critical success factors for e-learning acceptance: Confirmatory factor models, Computers \& Education, 49, 396-413. https://doi.org/10.1016/j.compedu.2005.09.004

Sharma, Sujeet Kumar \& Chandel, Jyoti Kumar. (2013). Technology Acceptance Model for the use of learning through websites among students in Oman. International Arab Journal of e-Technology, 3 (1), 44-49.

Song, S. M. (2010). E-learning: Investigating students' acceptance of online learning in hospitality programs. $\mathrm{PhD}$ Dissertation. Iowa State University.

Sun, P. C., Tsai, R. J., Finger, G., Chen, Y. Y., \& Yeh, D. (2008). What drives a successful e-Learning? An empirical investigation of the critical factors influencing learner satisfaction. Computers and Education 50, 1183-1202. https://doi.org/10.1016/j.compedu.2006.11.007

Waheed, M., \& Hussain, M. F. (2010). Empirical study of e-learner contentment towards e-Learning: Influential role of key factors. The 2010 MIT LINC Conference at Stratton Center on the MIT Campus. Boston, May 23 - 26.

Wright, K. B. (2005). Internet-based populations research: Advantages and disadvantages of online survey research, online questionnaire authoring software packages and web survey services. Journal of Computer-Mediated Communication, 10 (3). https://doi.org/10.1111/j.1083-6101.2005.tb00259 